\title{
Monetary Policy Divergence and Net Capital Flows: Accounting for Endogenous Policy Responses
}

\author{
Scott Davis
}

Andrei Zlate

Supervisory Research and Analysis (SRA) Working Papers present economic, financial and policy-related research conducted by staff in the Federal Reserve Bank of Boston's Supervisory Research and Analysis Unit. SRA Working Papers can be downloaded without charge at: http://www.bostonfed.org/publications/sra/ 


\title{
Monetary Policy Divergence and Net Capital Flows: Accounting for Endogenous Policy Responses*
}

\author{
Scott Davis ${ }^{\dagger}$ \\ Andrei Zlate $\ddagger$ \\ Federal Reserve Bank of Dallas \\ Federal Reserve Bank of Boston
}

July 2018

\begin{abstract}
This paper measures the effect of monetary tightening in key advanced economies on net capital flows around the world. Measuring this effect is complicated by the fact that the domestic monetary policies of affected economies respond endogenously to the foreign tightening shock. Using a structural VAR framework with quarterly panel data we estimate the impulse responses of domestic policy variables and net capital flows to a foreign monetary tightening shock. We find that the endogenous response of domestic monetary policy depends on each economy's capital account openness and exchange rate regime. We use a method to compute counterfactual impulse responses for net capital outflows under the assumption that the domestic policy rate does not respond to foreign monetary tightening. Our results suggests that failing to account for the endogenous response of domestic monetary policy biases down the estimated elasticity of net capital flows to foreign interest rates by as much as one-third for countries with open capital accounts.
\end{abstract}

JEL Classification: F3; F4; E5

Keywords: trilemma, structural VAR, counterfactual VAR, net capital inflows, exchange rates

*An earlier version of this paper was presented at the conference on "International Financial Integration in a Changing Policy Context - the End of an Era?" held at the European Commission in March 2018. We thank our discussant Luca Dedola and other participants in the conference for many helpful comments and suggestions. We also thank Menzie Chinn, Mick Devereux, and Robert Kollmann for editorial guidance. The views in this paper are solely those of the authors and should not be interpreted as reflecting the views of the Federal Reserve Banks of Boston or Dallas or the Federal Reserve System.

†Email: scott.davis@dal.frb.org

†'Email: andrei.zlate@bos.frb.org 


\section{Introduction}

As monetary policy in key advanced economies begins to normalize after having persisted at exceptionally accommodative levels for nearly 10 years, it is natural to ask what effect this normalization will have on world financial markets. In particular, what is the effect of monetary tightening on the volume of net capital flows around the world? How do the affected economies respond to foreign monetary tightening, and how does the response vary across economies? And finally, how can one disentangle the impact of foreign monetary normalization from that of the domestic policy responses on net capital inflows?

These questions may appear simple, but the measurement is not, because any attempt to quantify the impact of foreign monetary tightening on net capital flows is complicated by the fact that the response of domestic monetary policy in recipient countries is endogenous. The existing literature implies that, all else equal, higher interest rates in countries such as the United States reduce the net capital inflows to recipient economies. ${ }^{1}$ However, the extent of capital flight depends not just on the foreign monetary shock, but also on the domestic policy responses that are endogenous to the foreign shock. In fact, central banks are likely to raise interest rates and sell foreign exchange reserves following a monetary tightening in order to stem capital flight and local currency depreciation. Moreover, the endogenous policy response is likely to vary across countries depending on their capital account and exchange rate regimes.

Due to these complications, failing to account for the endogenous response of domestic monetary policy to foreign tightening is likely to understate the impact on capital flows, since the domestic response mitigates the full impact of the foreign shock. Moreover, by not accounting for important cross-sectional differences in the type and intensity of domestic

\footnotetext{
${ }^{1}$ See Eichengreen and Rose (2004), Eichengreen and Mody (1998), Forbes and Warnock (2012), Fratzscher (2012), Ghosh, Qureshi, Kima, and Zalduendo (2014), Ahmed and Zlate (2014), Byrne and Fiess (2016)). In particular, the "taper-tantrum" episode of 2013 demonstrated that the mere expectation of future monetary tightening in the United States can lead to a near sudden stop in net capital inflows to emerging markets (see Mishra, Moriyama, and N'Diaye (2014), Aizenman, Binici, and Hutchison (2014), Eichengreen and Gupta (2014), and Ahmed, Coulibaly, and Zlate (2017))
} 
policy responses, the literature is likely to miss the heterogeneous impact of foreign monetary tightening across recipient countries.

To rigorously quantify the impact of foreign monetary tightening on capital flows, we follow a two-step approach using a structural vector auto-regressive (SVAR) framework with panel data from 54 advanced and emerging market economies at the quarterly frequency from 1975:Q1 to 2015:Q4. There are ten variables in this structural VAR. The first four are foreign variables from large "base" countries/regions like the United States or the Euro Area, with each base country corresponding to one of the countries in our sample. The foreign variables include GDP growth, inflation, energy price inflation, and the policy interest rate. By controlling for foreign variables such as GDP growth and inflation, we can identify shocks to the foreign interest rate in the base country relevant for each country in our sample.

The remaining six variables in the SVAR framework are domestic variables for the 54 countries in our sample, and include GDP growth, inflation, net capital flows, the change in the exchange rate, central bank reserve accumulation, and the policy interest rate. Using this specification we can plot the response of domestic variables, including net capital outflows, to the foreign monetary policy shock in the relevant base country. This is the first step in our two-step approach.

In the second step we construct a series of hypothetical shocks to the domestic policy interest rate that would prevent the domestic rate from responding to the foreign monetary policy shock. These shocks are calibrated to cancel out the endogenous monetary response of the domestic central bank. They allow us to compute counterfactual impulse responses for every domestic variable in the model, and thus to infer the response of net capital outflows to the foreign monetary policy shock had there been no endogenous reaction of the domestic central bank. Importantly, to examine the variation in policy responses across country groups, we repeat the exercise for four country groups given by the interaction between floating/fixed exchange rate regimes and open/closed capital accounts, using the corresponding classifications from Klein and Shambaugh (2015) and Chinn and Ito (2008). 
The literature using counterfactuals in a structural VAR goes back to Bernanke, Gertler, and Watson (1997) and Sims and Zha (1998, 2006). These papers construct counterfactual impulse responses to highlight, for example, the role of endogenous changes in U.S. monetary policy to oil price shocks. Here, we instead construct counterfactuals to highlight the role of the endogenous responses of monetary policy in smaller economies to a monetary policy shock in core countries such as the United States. This approach to constructing counterfactuals is not without criticism, and may potentially run afoul of the Lucas Critique ((Lucas 1976)). To address such potential criticism, we calculate and present the "modesty statistics" from Leeper and Zha (2003) to show that the counterfactual interventions that arise from these hypothetical shocks are small enough that they would not generate substantial expectations-formation effects, and thus have little chance of running afoul of the Lucas Critique. However, we will show that consistently with Leeper and Zha (2003), even intra-regime policy interventions that are modest relative to the Lucas critique can result in substantial shifts in the projected paths of variables of interest, such as the net capital outflows.

Our results are as follows. First, following a foreign monetary tightening shock, countries with relatively open capital accounts respond with stronger increases in the domestic policy rates than countries with relatively closed capital accounts, and countries with fixed exchange rate regimes tend to respond by more than floaters. The result is in line with the trilemma framework, as it reflects the trade-off between capital account openness, exchange rate stability, and monetary policy independence. Second, open economies experience larger net capital outflows and greater currency depreciation than closed ones. Third, to illustrate the full effect of foreign monetary tightening on net capital outflows, we compute counterfactual impulse responses that prevent the domestic monetary policy from responding to the foreign shock. The results suggest that, if abstracting from the endogenous domestic policy response, foreign monetary tightening seems to trigger more net capital outflows, especially from economies with open capital accounts and fixed exchange rate regimes. Namely, fail- 
ing to account for the endogenous response of domestic monetary policy biases down the estimated elasticity of net capital outflows to foreign interest rates by as much as $1 / 4$ for countries with open capital accounts and floating exchange rate regimes, and by more than 1/3 for open peggers. Put differently, our results suggest that the endogenous policy response of affected economies to the foreign monetary tightening shock mitigates about $1 / 4$ of the net capital outflows at their peak for open floaters, and more than $1 / 3$ of net outflows for open peggers.

These results are important because they show the extent to which the elasticity of capital flows to foreign monetary policy decisions is understated if one fails to take into account the endogenous responses of domestic monetary policy. They also establish an intuitive relationship between the true elasticity of capital flows to foreign interest rates and country-level characteristics such as the level of capital account restrictions.

\section{$1.1 \quad$ Literature}

This paper contributes to the literature in a number of ways. First, our results add to the literature on the drivers of cross-border capital flows. Namely, the estimates from regressions of capital inflows on interest rates in recipient and source countries, or on their differential, may be subject to a reverse causation bias to the extent that a slowdown in capital inflows prompts the local central bank to raise the policy rate. The bias would cause the estimation to understate the elasticity of capital flows to interest rates, especially for countries that are more prone to responding to foreign monetary tightening. According to the trilemma, these are the countries with more open capital accounts and fixed exchange rate regimes. Our paper illustrates the existence of this bias and provides a way to overcome it.

Second, our results contribute to the literature on the effectiveness of capital account restrictions. Because open economies deploy a stronger monetary policy response than closed ones, the response differential may obscure differences in the reaction of capital flows of foreign shocks across open and closed economies. Thus, controlling for the endogenous response 
of domestic monetary policy is crucial to identify the effect of capital account restrictions on the reaction of capital flows. On the contrary, failing to account for the endogenous policy response may lead some papers to conclude that capital account restrictions do not affect the behavior of capital flows (see Clements and Kamil (2009), Ostry, Ghosh, Habermeier, Chamon, Qureshi, and Reinhardt (2010), Forbes and Warnock (2012), Ghosh, Qureshi, Kima, and Zalduendo (2014)).

Third, our results are consistent with the policy trilemma, which states that a country cannot at the same time have (1) an independent monetary policy, (2) a fixed exchange rate regime, and (3) an open capital account (see Mundell (1963) and Fleming (1962)). Our finding of a stronger monetary policy response in countries with open capital accounts and fixed exchange rates is consistent with Aizenman, Chinn, and Ito (2016), who show that financial conditions in peripheral economies are more closely linked to those in center economies especially for peripheral countries with financial openness or fixed exchange rates. More generally, our findings are consistent with studies that document the tendency for countries to mimic the monetary actions of a base-currency central bank like the Federal Reserve. Usually, the intention is to forestall a shift in capital flows that would lead to a sharp appreciation or depreciation of the currency. For instance, Shambaugh (2004), Obstfeld, Shambaugh, and Taylor (2005), and Klein and Shambaugh (2015) regress changes in the policy interest rate in one country on changes in a base country's interest rate. These papers find that the coefficient in this regression is significantly higher in countries with a pegged currency than in those with a floating currency, and in countries with open than with closed capital account. Hofmann and Takats (2015) find similar results in a sample of more recent, quarterly data. However, as in (Rey 2015), our results also suggest that even countries with a floating exchange rate tie their domestic monetary policy, at least partially, to that in base countries like the United States, which we find to be the case especially for countries with open capital accounts. Pasricha, Falagiarda, Bijsterbosch, and Aizenman (2015) show in a SVAR framework that active use of capital controls can lead to greater 
monetary policy autonomy, and Davis and Presno (2017) show the same in a DSGE model.

Fourth, our paper is related to the literature documenting the macroeconomic effects of different trilemma choices (see Aizenman, Chinn, and Ito (2011); Forbes and Klein (2015)). The sizeable responses of domestic monetary policy to foreign monetary tightening, which in our results could lead to as much as 10 basis points of additional increase in interest rates over two years for floaters and 35 basis points for peggers to every 100 basis points of foreign tightening, place urgency on considering the effects of reduced monetary policy autonomy on domestic output and inflation.

The rest of this paper is organized as follows. Section 2 introduces the econometric setup for the SVAR model and presents the dataset. Section 3 discusses the results, which contrast the observed impulse responses for net capital outflows and exchange rates to the counterfactual impulse responses that shut down the endogenous response of domestic monetary policy. Section 4 concludes.

\section{Econometric methodology and data}

\subsection{Econometric Methodology}

We calculate impulse responses using a SVAR model with panel data:

$$
\mathbf{B}_{0}\left[\begin{array}{c}
\mathbf{Y}_{t}^{*} \\
\mathbf{Y}_{t}
\end{array}\right]=\mathbf{B}(L)\left[\begin{array}{c}
\mathbf{Y}_{t-1}^{*} \\
\mathbf{Y}_{t-1}
\end{array}\right]+\left[\begin{array}{c}
\varepsilon_{t}^{*} \\
\varepsilon_{t}
\end{array}\right],
$$

where $\mathbf{Y}_{t}^{*}$ is a vector of four foreign variables from the relevant base countries and $\mathbf{Y}_{t}$ is a vector of six domestic variables. The foreign variables in $\mathbf{Y}_{t}^{*}$ include: the quarter over quarter (QoQ) log change in real GDP $\left(y_{t}^{*}\right)$, the QoQ log change in the GDP deflator $\left(\pi_{t}^{*}\right)$, the QoQ log change in energy prices $\left(e_{t}^{*}\right)$, and the level of the foreign policy interest rate $\left(r_{t}^{*}\right)$. The domestic variables in $\mathbf{Y}_{t}$ include: the QoQ log change in real GDP $\left(y_{t}\right)$, the QoQ log change in the GDP deflator $\left(\pi_{t}\right)$, net capital outflows excluding reserves $\left(o_{t}\right)$, the 
QoQ log change in the exchange rate relative to the base country currency $\left(x r_{t}\right)$, reserve accumulation $\left(f x_{t}\right)$, and the level of the home policy interest rate $\left(r_{t}\right) . \varepsilon_{t}^{*}$ and $\varepsilon_{t}$ are $4 \mathrm{x} 1$ and $6 \mathrm{x} 1$ vectors containing structural white-noise shocks. The quarterly net capital outflows excluding reserves and reserve accumulation are both normalized by the four-quarter lag of GDP.

We assume that foreign variables in core countries are unaffected by domestic variables or domestic shocks from the sample countries, either contemporaneously or with a lag, and thus we impose block restrictions that the entries in columns 5-10 in the first 4 rows of $\left(\mathbf{B}_{0}\right)^{-1}$ and $\mathbf{B}(L)$ are equal to zero.

To estimate the structural VAR, we first pre-multiply both sides of this equation by $\mathbf{B}_{0}^{-1}$ to obtain the reduced-form VAR:

$$
\left[\begin{array}{c}
\mathbf{Y}_{t}^{*} \\
\mathbf{Y}_{t}
\end{array}\right]=\mathbf{A}(L)\left[\begin{array}{c}
\mathbf{Y}_{t-1}^{*} \\
\mathbf{Y}_{t-1}
\end{array}\right]+\left[\begin{array}{l}
\mathbf{u}_{t}^{*} \\
\mathbf{u}_{t}
\end{array}\right]
$$

We then perform a Cholesky decomposition of the covariance matrix of the reduced form residuals, $\left[\begin{array}{c}\mathbf{u}_{t}^{*} \\ \mathbf{u}_{t}\end{array}\right]\left[\begin{array}{c}\mathbf{u}_{t}^{*} \\ \mathbf{u}_{t}\end{array}\right]^{\prime}=\mathbf{B}_{0}^{-1}\left(\mathbf{B}_{0}^{-1}\right)^{\prime}$, in order to identify the lower-triangular matrix $\mathbf{B}_{0}$. Identification through the recursive Cholesky identification scheme requires one to specify an ordering of variables. We use the ordering given by the introduction of the variables above. When identifying the shock to the foreign interest rate, we order the foreign policy rate after all other foreign variables, and thus assume that the foreign policy rate is affected by contemporaneous shocks to all other foreign variables, but it only affects all other foreign variables with a lag.

We order all domestic variables after the foreign variables, so foreign variables can have a contemporaneous effect on domestic variables. Furthermore the domestic policy interest rate is ordered last among all domestic variables, and thus assume that the domestic policy interest rate is affected by contemporaneous shocks to all foreign and domestic variables, but 
it only affects all other domestic variables with a lag.

In the results section, we begin by presenting impulse responses to a 100 basis point shock to the foreign policy interest rate, given by $\varepsilon_{1}^{*}=[0,0,0,1]^{\prime}$ and $\varepsilon_{1}=[0,0,0,0,0,0]^{\prime}$. As will be discussed, we find that the positive shock to the foreign policy interest rate leads to an endogenous increase in the domestic policy interest rate. To illustrate the extent to which this endogenous domestic policy response mitigates the rise in net capital outflows following the foreign shock, we construct a counterfactual scenario by adding a series of hypothetical shocks to offset the endogenous domestic policy response. Thus, our counterfactual scenario mimics the case in which the domestic policy interest rate is held constant despite the foreign monetary tightening.

To construct the series of hypothetical shocks to the domestic policy interest rate, we begin with the SVAR in (1):

$$
\mathbf{B}_{0}\left[\begin{array}{c}
\mathbf{Y}_{t}^{*} \\
y_{t} \\
\pi_{t} \\
o_{t} \\
x r_{t} \\
f x_{t} \\
r_{t}
\end{array}\right]=\mathbf{B}(L)\left[\begin{array}{c}
\mathbf{Y}_{t-1}^{*} \\
y_{t-1} \\
\pi_{t-1} \\
o_{t-1} \\
x r_{t-1} \\
f x_{t-1} \\
r_{t-1}
\end{array}\right]+\left[\begin{array}{c}
\varepsilon_{t}^{*} \\
\varepsilon_{t}
\end{array}\right],
$$

in which we have written out the 6 domestic variables in $\mathbf{Y}_{t}$. Since all foreign variables are unaffected by domestic shocks, we leave the vector of four foreign variables written as $\mathbf{Y}_{t}^{*}$.

In this setup, we consider a shock to the foreign policy rate at period $t=1$. Since $\mathbf{B}_{0}$ is lower triangular, this shock will affect contemporaneously the domestic monetary policy rate. In the counterfactual scenario, to offset the domestic policy response, we introduce an additional structural shock $\tilde{\varepsilon}_{1}^{r}$ to the domestic policy rate, which is calibrated to ensure that the total response of the domestic policy rate is 0 in the first period: 


$$
\left[\begin{array}{c}
\mathbf{Y}_{1}^{*} \\
\tilde{y}_{1} \\
\tilde{r}_{1} \\
\tilde{o}_{1} \\
x \tilde{r}_{1} \\
f \tilde{x}_{1} \\
0
\end{array}\right]=\mathbf{B}_{0}^{-1}\left[\begin{array}{c}
\varepsilon_{1}^{*} \\
\widetilde{\varepsilon}_{1}
\end{array}\right]=\mathbf{B}_{0}^{-1}\left[\begin{array}{c}
\varepsilon_{1}^{*} \\
0 \\
0 \\
0 \\
0 \\
0 \\
0
\end{array}\right]+\mathbf{B}_{0}^{-1}\left[\begin{array}{c}
0 \\
0 \\
0 \\
0 \\
0 \\
0 \\
\tilde{\varepsilon}_{1}^{r}
\end{array}\right]
$$

where a tilda " " indicates the response of a variable under the counterfactual scenario that incorporates the counterfactual shock to the home policy rate. To calibrate the counterfactual shock to the home policy rate, we pre-multiply each side of the above equation by a row vector with ten columns, where each column is set at zero except for the tenth, which is set at one. By doing so, the above equation becomes:

$$
-\mathbf{B}_{0}^{-1}(10,4)=\mathbf{B}_{0}^{-1}(10,10) \tilde{\varepsilon}_{1}^{r}
$$

where $\mathbf{B}_{0}^{-1}(i, j)$ is the value in the $i$-th row and the $j$-th column of the matrix $\mathbf{B}_{0}^{-1}$, and $\tilde{\varepsilon}_{1}^{r}$ is the counterfactual shock to the home policy rate in the first period that would be necessary to hold the home policy rate constant following the shock to the foreign policy rate.

The counterfactual shock is extended in all subsequent periods $t>1$ in order to keep the domestic policy rate constant: 


$$
\left[\begin{array}{c}
\mathbf{Y}_{t}^{*} \\
\tilde{y}_{t} \\
\tilde{\pi}_{t} \\
\tilde{o}_{t} \\
x \tilde{r}_{t} \\
f \tilde{x}_{t} \\
0
\end{array}\right]=\mathbf{B}_{0}^{-1} \mathbf{B}(L)\left[\begin{array}{c}
\mathbf{Y}_{t-1}^{*} \\
\tilde{y}_{t-1} \\
\tilde{\pi}_{t-1} \\
\tilde{o}_{t-1} \\
x \tilde{r}_{t-1} \\
f \tilde{x}_{t-1} \\
0
\end{array}\right]+\mathbf{B}_{0}^{-1}\left[\begin{array}{c}
0 \\
0 \\
0 \\
0 \\
0 \\
0 \\
\tilde{\varepsilon}_{t}^{r}
\end{array}\right]
$$

Again, one can highlight the 10th equation in this SVAR model by pre-multiplying it by the row vector with ten elements, where each element is zero except for the tenth element, which is one:

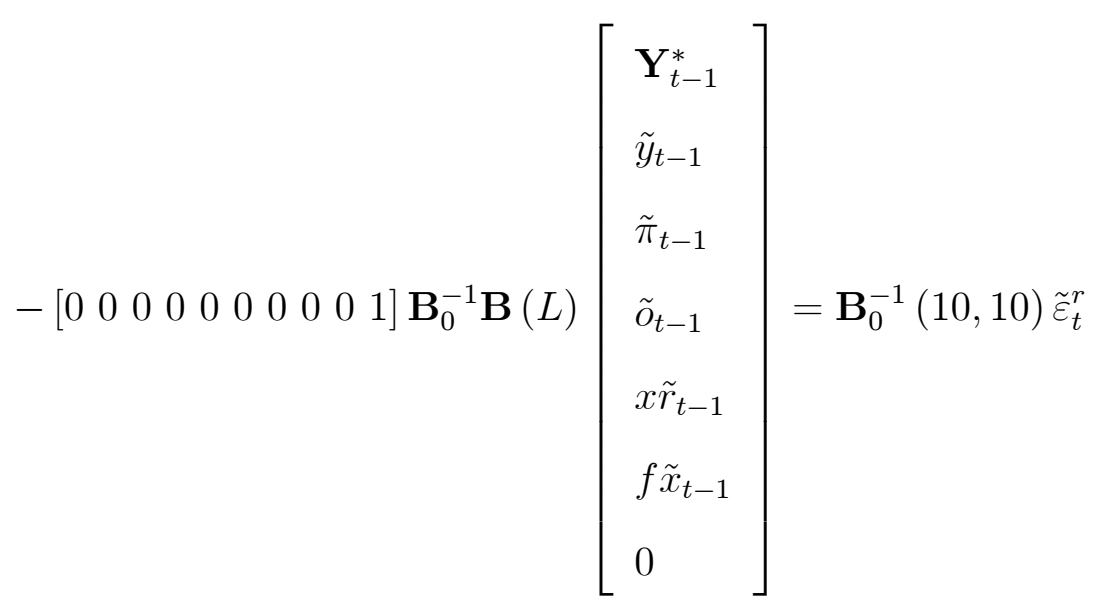

Our approach gives the series of counterfactual shocks to the home policy rate $\tilde{\varepsilon}_{t}^{r}$ that would be necessary to hold the home policy rate constant following a shock to the foreign policy rate.

\subsection{Data}

The full list of countries included in the panel VAR is presented in Table 1. For each country in our sample, the table provides the "base" country used to pick the relevant foreign policy 
rate and the foreign currency against which to compute the exchange rate. ${ }^{2}$ To measure the effect of interest rate divergence on capital flows and exchange rates, we designate such a base foreign country for each country in our sample, with the base considered to be the source of the exogenous monetary policy shock. Many studies have used the U.S. dollar as the base currency and the U.S. Fed Funds rate as the base country interest rate throughout the sample. However, it is plausible that the primary international relation for some of the countries in our sample is not with the United States, so to accurately measure the effect of interest rate divergence on capital flows, we designate a different base foreign country for each country in our sample.

We pair our countries to base countries like in Shambaugh (2004). When a country pegs or partially pegs its currency to a base country's currency, the designation is straightforward (e.g., the peg of the Hong Kong dollar to the U.S. dollar). However, when the country does not peg, the designation is not trivial and requires a judgement call. Shambaugh (2004) bases this choice on historical relationships or proximity to a nearby dominant economy (e.g., Malaysia is the base country for Singapore, Australia is the base country for New Zealand, and India is the base country for Sri Lanka).

Except for one variable, all data series are from the IMF's International Financial Statistics. The one exception is the QoQ log change in energy prices, which is taken from the World Bank's energy price index. For domestic and foreign GDP growth and inflation, we use the QoQ log change in the GDP volume index and deflator. The data on private net capital outflows and reserve accumulation at the quarterly frequency are from the IMF balance of payments (BPM6). Private net capital outflows and reserve accumulation are both normalized by GDP, lagged 4 quarters. For the domestic and foreign interest rates, we use policy interest rates and, in a few cases depending on data availability, we use a short-term money market rate. When reporting the QoQ change in the exchange rates, an increase

\footnotetext{
${ }^{2}$ USA: U.S. dollar; DEU: German currency (mark and then euro); AUS: Australian dollar; IND: Indian rupee; MYS: Malaysian ringgit.
} 
denotes local currency depreciation. ${ }^{3}$

One challenge arises from the fact that in recent years, the central banks of our two major base countries, the Federal Reserve and the ECB, have used instruments other than the usual policy interest rate. To address this issue, we include the shadow short-term interest rates for the United States, the Euro Area, the United Kingdom, and Japan from Krippner (2013). For the United States, the Euro Area, and the United Kingdom, the Krippner shadow rate replaces the policy rate series from 2009 to the end of our sample in 2015. For Japan, the Krippner shadow rate replaces the policy rate from 1999 to the end of our sample.

Country-quarter observations are divided into four categories: (1) those corresponding to countries with a floating currency and an open capital account, (2) those with a floating currency and a closed capital account, (3) those with a fixed currency and an open capital account, and (4) those with a fixed currency and a closed capital account. The distinction of whether a country has a fixed or floating exchange rate regime in a given year is taken from Klein and Shambaugh (2015), whereby a country has a fixed currency in a given year if the movement in the exchange rate relative to the base country currency in a given year does not exceed 5\%. Unlike in Klein and Shambaugh, who use 3 groups given by pegs, soft pegs, and floaters, we combine their peg and soft peg categories into one single group.

The distinction between country-quarters with open vs. closed capital account regime is based on the Chinn and Ito (2008) index of capital account openness normalized on a 0-1 scale, where 0 indicates a closed capital account and 1 indicates an open capital account. In a given year, a country is considered to have an open capital account if the value of the Chinn-Ito index for that year is greater than 0.5 , and it is considered to have a closed capital account if the index is less than 0.5 .

\footnotetext{
${ }^{3}$ We removed outliers defined as follows: (1) Country-quarter observations where the absolute value of net capital flows is greater than $20 \%$ of GDP. (2) Observations where net capital flows are exactly zero (since many times statistical agencies would write zero for missing observations). (3) Observations where the absolute vale of the QoQ change in the interest rate is greater than $9 \%$. (4) Observations where the absolute value of the QoQ change in the exchange rate is greater than $10 \%$. Data cleaning restrictions (1), (3), and (4) help eliminate any obvious crisis or sudden stop episodes from the data set, which would be a source of outliers.
} 
Both the currency index and the Chinn and Ito (2008) capital account openness index are annual, but the data in the VAR is at a quarterly frequency. Therefore, the values of the currency index and capital account openness index in a given year are assumed to apply to every quarter of that year. Also, it should be noted that the four groups include countryquarter observations, since a given country can transition between groups over time. For a country that moves toward liberalizing its capital account during the sample period, the country-quarter observations for that country may fall into the closed capital account groups early in the sample period, but switch to one of the open capital account groups later in the sample period.

Table 2 presents the descriptive statistics for the full sample, and also separately for the four groups of economies defined by the interaction between their capital account and exchange rate regimes. The roughly 3,400 observations in the full sample are distributed about evenly among the four country-quarter groups, although the number of open peggers stands out a bit. As expected, countries with open capital accounts seem to experience more volatile capital flows than their closed counterparts. Also, floaters experience a less volatile pace of reserve accumulation, but greater exchange rate volatility than peggers. For instance, the standard deviations of exchange rate changes are about 5 percentage points for floaters vs. 2 percentage points for peggers.

\section{Results}

\subsection{Results from Structural VARs}

The responses all domestic variables to a 100 b.p. shock to the foreign policy rate are presented in figures 1-4. Figure 1 presents the shock responses for countries with a floating currency and an open capital account, figure 2 presents the responses for countries with a floating currency and a closed capital account, figure 3 is for countries with an exchange rate

peg and an open capital account, and figure 4 is for countries with an exchange rate peg and 
a closed capital account. ${ }^{4}$

The impulse responses in figure 1 show that for a country with a floating currency and an open capital account, following the 100 b.p. increase in the foreign interest rate, GDP growth slows, and there is a slight, but not statistically significant fall in inflation. There is a rise in the domestic policy rate of about 5 b.p. on impact, increasing to about 10 b.p. after 20 quarters, and the response is barely statistically significant. There is a sharp depreciation of the currency of about $0.4 \%$ on impact. The ratio of net capital outflows to GDP increases by about $0.15 \%$ of GDP at its peak. Meanwhile, central bank reserve accumulation falls by about $0.1 \%$ of GDP on impact.

Turning now to figure 2 , in a country with a floating currency but a relatively closed capital account, the behavior of GDP growth and inflation following the shock to the foreign policy rate is similar to that in a country with an open capital account. The domestic policy rate actually falls on impact, but the change is not statistically significant. The currency depreciates by about $0.2 \%$. There is an increase in net capital outflows on impact, but after a few quarters it is not statistically significant. Reserve accumulation falls sharply by about $0.3 \%$ of GDP.

Next we turn to countries with fixed exchange rate regimes in figures 3 and 4 . In countries with a pegged exchange rate, the responses of GDP growth and inflation are similar to the responses in countries with a floating currency. But whereas floaters implement nearly no change in the domestic policy rate, the domestic policy rate increases by around 30 b.p. in peggers with a closed capital account, and by 35 b.p. in peggers with an open capital account. Furthermore, the depreciation in the currency is small in both sets of countries, at about $0.1 \%$ in countries with an open capital account, and not statistically significant in

\footnotetext{
${ }^{4}$ As shown by Pesaran and Smith (1995) pooling these country-quarter observations and estimating a panel VAR can lead to biased coefficients when there is cross-country heterogeneity in the coefficients. By pooling countries into these four groups prior to estimation, we help address this potential source of bias, since presumably more heterogeneity exists across groups than across countries within a group. To test for heterogeneity within groups we can compute responses for individual countries in the limited number of countries that remain in the same group throughout the sample period. The responses from these nonpooled regressions using an individual country within a group are consistent with the pooled responses for that group.
} 
countries with a closed capital account. The net capital outflows increase by $0.1 \%$ of GDP in countries with an open capital account, and do not show a statistically significant change in countries with a closed capital account. Meanwhile, central bank reserve accumulation falls by around $0.2-0.3 \%$ of GDP in both sets of countries.

The most substantial differences across the four groups of countries in figures 1-4 concern the responses of the home country policy interest rate. In countries with a floating currency, the home country policy rate does not change or increases by at most 10 b.p. following the 100 b.p. shock to the foreign interest rate, while in a country with a pegged currency the response of the home country policy rate is about 30-35 b.p. increase.

The fact that the home policy rate is much less responsive to shocks to the foreign policy rate in a country with a floating currency is shown again in variance decomposition results in table 3. The table shows the percent of the forecast error variance of the home policy rate in each of the four groups of countries that is explained by shocks to each of the 10 variables in the model at 1-5 year forecast horizons. Thus, in countries with a floating currency and an open capital account, only $1 \%$ of the forecast error variance of the home policy rate at a 5 year horizon is explained by shocks to the foreign policy rate. For countries with a floating currency and a closed capital account this share falls to nearly $0 \%$. Meanwhile, the share of the variance in the home policy rate explained by shocks to the foreign policy rate is much higher in countries with a pegged currency. In countries with a pegged currency and a relatively closed capital account the share is $12 \%$, and in countries with a pegged currency and an open capital account this share rises to $19 \%$.

As expected, open economies experience larger net capital outflows and greater currency depreciation than closed ones in response to the foreign monetary tightening shock. Also, among open economies, floaters lose less foreign exchange reserves than peggers, which reflects their softer foreign exchange intervention to curb their currency depreciation. 


\subsection{Results from Counterfactual VARs}

In response to an increase in the foreign policy rate, the home country central bank may raise the policy interest rate in an attempt to mitigate some of the increase in net capital outflows (or the fall in net inflows) resulting from the divergence between the home and foreign interest rates. It is therefore natural to ask how successful this policy was in stemming the fall in net inflows. What would net capital flows have been in the absence of these domestic policy changes?

The counterfactual VAR model results discussed in this section can be used to plot the responses of net capital outflows in each of the four country groups under the alternative scenario where the home country policy interest rate does not respond to the foreign policy interest rate shock. As described in the last section, we compute the counterfactual impulse responses by calibrating a series of shocks to the home country policy rate that would keep the home policy rate unchanged. The calibration of these is described in equation (7).

The calibrated shocks to the home country policy interest rate that would be necessary to keep the home country policy rate constant following the shock to the foreign interest rate are shown in figure 5. The counterfactual shock necessary to keep the home policy rate constant is largest in the group with a pegged currency and an open capital account. The hypothetical shocks are the second largest in countries with a pegged currency and a closed capital account. Meanwhile the hypothetical shock is small in countries with a floating currency and an open capital account and the hypothetical shock is nearly zero in countries with a floating currency and a closed capital account. This result reflects the fact that the desire to raise the home policy rate following the foreign shock is strongest when a country has a pegged currency and an open capital account, and that capital account restrictions reduce the pressure on the home interest rate.

But what is interesting to note in figure 5 is that the shocks necessary to keep the domestic policy rate fixed at zero are relatively small. The scale of the figure is in basis points, and thus following a 100 b.p. shock to the foreign interest rate, the hypothetical shock to the 
domestic interest rate required to keep the domestic policy rate constant is at most 8 b.p. per quarter in the few quarters following the shock. But this largest hypothetical shock dissipates relatively quickly, as it falls to around 6 b.p. after 2 years, and to 4 b.p. after 3 or 4 years.

The path of net capital outflows (excluding reserves) following a shock to the foreign policy rate is presented in figure 6 . The blue impulse responses are the actual impulse responses discussed earlier in figures 1-4, with the solid line depicting the point estimate of the response and the dotted lines showing $68 \%$ confidence bands. The red dashed lines are the counterfactual response when the additional series of shocks to the home policy rate are fed into the model to keep the home policy rate constant.

In this setup, the gap between the red and blue lines in the figure represent the amount of the increase in net capital outflows that is mitigated by the endogenous response of domestic monetary policy. Controlling for the capital account regime (within columns), this gap is larger for the set of countries with a fixed exchange rate rather than floating exchange rates. Alternatively, controlling for the exchange rate regime (within rows), this gap is larger for countries with an open capital account than with a closed capital account regime. Importantly, the counterfactual response in the set of countries with pegged exchange rates and open capital accounts is the only counterfactual response that does not lie within the confidence bands of the original impulse response. Quantitatively, for open peggers, the endogenous policy response seems to mitigate more than $1 / 3$ of net outflows at their peak.

After accounting for the endogenous policy response, the effect of a foreign interest rate shock is quantitatively similar in both sets of countries with an open capital account; the 100 b.p. shock leads to about a 0.10 -to- $0.15 \%$ of GDP increase in net capital outflows. Similarly, after accounting for the endogenous policy response, the effect of a foreign interest rate shock is quantitatively similar in both sets of countries with a closed capital account; the 100 b.p. shock leads to about a 0 to $0.05 \%$ of GDP increase in net capital outflows. 


\subsubsection{Lucas Critique}

Given our approach to compute counterfactual impulse responses, one natural question arises on whether these counterfactual simulations may run afoul of the Lucas Critique ((Lucas 1976)). The counterfactual aims to remove the impact of domestic monetary policy from the response of net capital outflows by asking what the net outflows would have been if the domestic policy rate were held constant. But of course, the estimated parameters in the transition matrix $\mathbf{B}(L)$ in equation (1) are calculated from data in an environment in which agents expect a domestic monetary policy reaction. If instead agents had known that the domestic interest rate would be held fixed, they may have changed their decisions, and thus the transition matrix $\mathbf{B}(L)$ would be inaccurate for computing counterfactual impulse responses.

Leeper and Zha (2003) develop a test of whether a counterfactual VAR analysis would run afoul of the Lucas Critique. This test requires constructing "modesty statistics" and verifying whether those statistics lie within a certain range. To compute these statistics, we begin by rearranging the VAR model in equation (1) to express the value of the observed variables in period $t+h,\left[\begin{array}{c}\mathbf{Y}_{t+h}^{*} \\ \mathbf{Y}_{t+h}\end{array}\right]$, as a function of their expected value given all information known at time $t, E_{t}\left(\left[\begin{array}{c}\mathbf{Y}_{t+h}^{*} \\ \mathbf{Y}_{t+h}\end{array}\right]\right)$, and the vector of direct effects of the shocks that occurred between period $t+1$ and $t+h, \sum_{s=0}^{h-1} \mathbf{B}_{1}^{s} \mathbf{B}_{0}^{-1}\left[\begin{array}{c}\varepsilon_{t+h-s}^{*} \\ \varepsilon_{t+h-s}\end{array}\right]$ :

$$
\left[\begin{array}{c}
\mathbf{Y}_{t+h}^{*} \\
\mathbf{Y}_{t+h}
\end{array}\right]=\sum_{s=0}^{h-1} \mathbf{B}_{1}^{s} \mathbf{B}_{0}^{-1}\left[\begin{array}{c}
\varepsilon_{t+h-s}^{*} \\
\varepsilon_{t+h-s}
\end{array}\right]+E_{t}\left(\left[\begin{array}{c}
\mathbf{Y}_{t+h}^{*} \\
\mathbf{Y}_{t+h}
\end{array}\right]\right)
$$

where for ease of notation, we have gone ahead and written the original VAR model as a $\operatorname{VAR}(1)$ where the transition matrix is $\mathbf{B}_{1}$.

Let $I_{t}$ be the set of hypothetical policy interventions for the $h$ periods (i.e., our hypo- 
thetical shocks to the domestic policy rate) following the shock to the foreign interest rate at time $t$, where the sequence $I_{t}=\left\{\tilde{\varepsilon}_{r, t}, \tilde{\varepsilon}_{r, t+1}, \ldots, \tilde{\varepsilon}_{r, t+h}\right\}$ is plotted for our various country groups in figure 5. Using this notation, one can express the vector of direct effects of the counterfactual shocks to the home policy rate:

$$
\begin{aligned}
\boldsymbol{\eta}_{r, t+h} & =E_{t}\left(\left[\begin{array}{c}
\mathbf{Y}_{t+h}^{*} \\
\mathbf{Y}_{t+h}
\end{array}\right] \mid I_{t}\right)-E_{t}\left(\left[\begin{array}{c}
\mathbf{Y}_{t+h}^{*} \\
\mathbf{Y}_{t+h}
\end{array}\right]\right) \\
& =\sum_{s=0}^{h-1} \mathbf{B}_{1}^{s} \mathbf{B}_{0}^{-1}\left[\begin{array}{c}
\mathbf{0} \\
\tilde{\varepsilon}_{t+h-s}
\end{array}\right]
\end{aligned}
$$

The vector of modesty statistics, $\boldsymbol{\eta}_{r, t+h}^{*}$, in Leeper and Zha (2003) scales this direct effect $\boldsymbol{\eta}_{r, t+h}$ by its standard deviation, where the vector of standard deviations is given by square root of the diagonal of $\sum_{s=0}^{h-1}\left(\mathbf{B}_{1}^{s} \mathbf{B}_{0}^{-1}\right)\left(\mathbf{B}_{1}^{s} \mathbf{B}_{0}^{-1}\right)^{\prime}$.

Intuitively, the vector of direct effects $\boldsymbol{\eta}_{r, t+h}$ measures the forecast error at horizon $h$ due to the series of hypothetical shocks to the domestic interest rate between $t$ and $t+h$. The modesty statistic then scales this forecast error by the square root of the historical forecast error variance. And thus the modesty statistic for variable $i$ at horizon $h$ asks if the forecast error of variable $i$ due to the hypothetical shocks to the domestic interest rate between period $t$ and $t+h$ is large relative to the usual forecast error variance of variable $i$. If it is, then the counterfactual simulation runs afoul of the Lucas Critique, since the hypothetical shocks are large enough to be noticed by agents and causes agents to change their behavior. If it is not, the forecast errors due to the hypothetical shocks are small enough that they would not cause agents to change their behavior.

As defined by Leeper and Zha (2003), the intervention is modest at horizon $h$ for variable $i$ if the absolute value of the $i^{\text {th }}$ element of the scaled direct effect $\boldsymbol{\eta}_{r, t+h}^{*}$ is less than 2 . These modesty statistics, $\boldsymbol{\eta}_{r, t+h}^{*}$, for each of the 6 domestic variables in response to hypothetical 
shocks to the domestic interest rate are presented in table 4. The table presents the modesty statistics for horizons $h$ between 1 and 5 years. Of course in the counterfactual results in figure 6 we plot the counterfactual responses when the series of hypothetical shocks lasts all 5 years.

The table of modesty statistics shows that the absolute value of these statistics are small and nowhere near 2. Not surprisingly the statistics are the largest in absolute value in the set of countries with a pegged currency and an open capital account. In addition, the modesty statistics are largest in absolute values for deviations in the domestic interest rate, since the hypothetical shock was a shock to the domestic interest rate. But even here, the modesty statistics are much smaller than 2 , and thus it is safe to say that the counterfactual simulations do not run afoul of the Lucas Critique.

\section{Conclusion}

This paper shows that measuring the elasticity of net capital flows to foreign monetary policy shocks is complicated by the endogenous responses of domestic monetary policy in

affected economies. In response to the current wave of monetary policy tightening in key advanced economies, such as the United States and the Euro Area, central banks in peripheral economies are likely to raise their policy interest rates in order to curtail a fall in capital inflows and currency depreciation. However, the extent to which central banks will raise their policy rates in such a scenario is likely to depend on factors like the capital account and exchange rate regimes. Our results suggest that failing to account for the endogenous response of domestic monetary policy would bias down the estimated elasticity of net capital flows to changes in foreign interest rates by as much as $1 / 4$ for floaters and more than $1 / 3$ for peggers with open capital accounts.

Raising the domestic interest rate is not the only policy response of central banks to foreign monetary tightening, since central banks can also sell foreign exchange reserves to 
arrest currency depreciation. Aizenman and Sun (2012) document and explain the size of reserve depletion in many emerging markets during the Global Financial Crisis. Davis (2017) uses a regression framework like that in Klein and Shambaugh (2015) to show that countries with high levels of foreign exchange reserves are less likely to move their domestic interest rate in response to a change in the foreign interest rate. Our results already show the extent to which various countries choose to let their currencies depreciate vs. sell foreign exchange reserves in response to the foreign interest rate shock. Therefore, one interesting expansion of our framework would be to consider that the response of foreign exchange reserves is itself an endogenous policy response, and examine if accounting for this additional endogenous policy action affects the response of net capital flows in the context of foreign monetary tightening shocks. 


\section{References}

Ahmed, S., B. Coulibaly, and A. Zlate (2017): "International Financial Spillovers to Emerging Market Economies: How Important Are Economic Fundamentals?," Journal of International Money and Finance, 76, 133-152.

Ahmed, S., And A. Zlate (2014): "Capital flows to emerging market economies: a brave new world?," Journal of International Money and Finance, 48, 221-248.

Aizenman, J., M. Binici, and M. M. Hutchison (2014): "The transmission of Federal Reserve tapering news to emerging financial markets," NBER Working Paper No. 19980.

Aizenman, J., M. D. Chinn, And H. Ito (2011): "Surfing the waves of globalization: Asia and financial globalization in the context of the trilemma," Journal of the Japanese and International Economies, 25(3), 290-320.

- (2016): "Monetary policy spillovers and the trilemma in the new normal: Periphery country sensitivity to core country conditions," Journal of International Money and Finance, 68, 298-330.

Aizenman, J., And Y. Sun (2012): "The financial crisis and sizable international reserves depletion: From $\dddot{£ j f e a r ~ o f ~ f l o a t i n g i ̈ £ ~ t o ~ t h e ~ i ̈ £ j f e a r ~ o f ~ l o s i n g ~ i n t e r n a t i o n a l ~ r e s e r v e s i ̈ £ i ?, " ~}$ International Review of Economics \& Finance, 24, 250-269.

Bernanke, B. S., M. Gertler, and M. Watson (1997): "Systematic monetary policy and the effects of oil price shocks," Brookings Papers on Economic Activity, 1997(1), 91-157.

Byrne, J. P., And N. Fiess (2016): "International capital flows to emerging markets: National and global determinants," Journal of International Money and Finance, 61, 82100.

Chinn, M. D., And H. Ito (2008): "A new measure of financial openness," Journal of comparative policy analysis, 10(3), 309-322.

Clements, B., and H. Kamil (2009): "Are capital controls effective in the 21st century? The recent experience of Colombia," IMF Working Paper no. 09/30.

Davis, J. S. (2017): "External debt and monetary policy autonomy," Ensayos sobre Política Económica, 35(82), 53-63.

Davis, J. S., And I. Presno (2017): "Capital Controls and Monetary Policy Autonomy in a Small Open Economy," Journal of Monetary Economics, 85, 114-130.

Eichengreen, B., And P. Gupta (2014): "Tapering talk: the impact of expectations of reduced federal reserve security purchases on emerging markets," World Bank Policy Research Working Paper, (6754).

Eichengreen, B., And A. Mody (1998): "Interest rates in the north and capital flows to the south: is there a missing link?," International finance, 1(1), 35-57. 
Eichengreen, B., And A. K. Rose (2004): "Staying Afloat When the Wind Shifts: External Factors and Emerging-Market Banking Crises," in Money, Capital Mobility, and Trade: Essays in Honor of Robert A. Mundell, ed. by G. Calvo, M. Obstfeld, and R. Dornbusch, pp. 171-205. MIT Press.

Fleming, J. M. (1962): "Domestic Financial Policies Under Fixed and Under Floating Exchange Rates," Staff Papers, International Monetary Fund, 9, 369-379.

Forbes, K., And F. E. Warnock (2012): "Capital flow waves: Surges, stops, flight, and retrenchment," Journal of International Economics, 88, 235-251.

Forbes, K. J., And M. W. Klein (2015): "Pick your poison: the choices and consequences of policy responses to crises," IMF Economic Review, 63(1), 197-237.

Fratzscher, M. (2012): "Capital flows, push versus pull factors and the global financial crisis," Journal of International Economics, 88(2), 341-356.

Ghosh, A. R., M. S. Qureshi, J. I. Kima, and J. Zalduendo (2014): "Surges," Journal of International Economics, 92, 266-285.

Hofmann, B., and E. Takats (2015): "International monetary spillovers," BIS Quarterly Review, September.

Klein, M. W., and J. C. Shambaugh (2015): "Rounding the Corners of the Policy Trilemma: Sources of Monetary Policy Autonomy," American Economic Journal: Macroeconomics, 7(4), 33-66.

KRIPPNER, L. (2013): "Measuring the stance of monetary policy in zero lower bound environments," Economics Letters, 118(1), 135-138.

Leeper, E. M., And T. Zha (2003): "Modest policy interventions," Journal of Monetary Economics, 50(8), 1673-1700.

LuCAS, R. E. (1976): "Econometric policy evaluation: A critique," Carnegie-Rochester conference series on public policy, 1, 19-46.

Mishra, P., K. Moriyama, and P. N'Diaye (2014): "Impact of Fed Tapering Announcements on Emerging Markets," .

Mundell, R. A. (1963): "Capital Mobility and Stabilization Policy under Fixed and Flexible Exchange Rates," Canadian Journal of Economics and Political Science, 29(4), 475485.

Obstfeld, M., J. C. Shambaugh, and A. M. Taylor (2005): "The trilemma in history: tradeoffs among exchange rates, monetary policies, and capital mobility," Review of Economics and Statistics, 87(3), 423-438.

Ostry, J. D., A. R. Ghosh, K. Habermeier, M. Chamon, M. S. Qureshi, and D. Reinhardt (2010): "Capital inflows: The role of controls," IMF Staff Position Note, $S P N / 10 / 04$. 
Pasricha, G., M. Falagiarda, M. Bijsterbosch, and J. Aizenman (2015): "Domestic and Multilateral effects of capital controls in emerging markets," NBER Working Paper no. 20822.

Pesaran, M. H., and R. Smith (1995): "Estimating long-run relationships from dynamic heterogeneous panels," Journal of Econometrics, 68(1), 79-113.

Rey, H. (2015): "Dilemma not Trilemma: The Global Financial Cycle and Monetary Policy Independence," NBER Working Paper No. 21162.

Shambaugh, J. C. (2004): "The effect of fixed exchange rates on monetary policy," The Quarterly Journal of Economics, 119(1), 301-352.

Sims, C. A., And T. Zha (1998): "Does Monetary Policy Generate Recessions?," Federal Reserve Bank of Atlanta, Working Paper no. 98-12.

(2006): "Where there regime switches in U.S. monetary policy?," American Economic Review, 96(1), 54-80. 
Table 1: Countries in the panel VARs.

\begin{tabular}{rr}
\hline \hline Argentina (USA) & Ukraine (USA) \\
Armenia (USA) & Croatia (DEU) \\
Australia (USA) & Czech Republic (DEU) \\
Bolivia (USA) & Denmark (DEU) \\
Brazil (USA) & Estonia (DEU) \\
Canada (USA) & Finland (DEU) \\
Chile (USA) & France (DEU) \\
China (USA) & Greece (DEU) \\
Colombia (USA) & Hungary (DEU) \\
Germany (USA) & Italy (DEU) \\
Hong Kong (USA) & Latvia (DEU) \\
India (USA) & Lithuania (DEU) \\
Indonesia (USA) & Macedonia (DEU) \\
Israel (USA) & Netherlands (DEU) \\
Japan (USA) & Norway (DEU) \\
Jordan (USA) & Poland (DEU) \\
Korea (USA) & Portugal (DEU) \\
Kyrgyz Republic (USA) & Romania (DEU) \\
Mexico (USA) & Slovak Republic (DEU) \\
Moldova (USA) & Slovenia (DEU) \\
Paraguay (USA) & Spain (DEU) \\
Peru (USA) & Sweden (DEU) \\
Philippines (USA) & Switzerland (DEU) \\
Russia (USA) & United Kingdom (DEU) \\
South Africa (USA) & New Zealand (AUS) \\
Thailand (USA) & Sri Lanka (IND) \\
Turkey (USA) & Singapore (MYS) \\
\hline \hline &
\end{tabular}


Table 2: Descriptive statistics for the entire sample of country-quarter observations and the four subsamples.

\begin{tabular}{|c|c|c|c|c|c|c|c|}
\hline Complete sample & Obs & Mean & Median & St. & Dev. & Min & Max \\
\hline Foreign GDP growth, q/q & 3,398 & 1.63 & 1.41 & & 1.80 & -5.99 & 8.40 \\
\hline Foreign inflation, $\mathrm{q} / \mathrm{q}$ & 3,398 & 0.60 & 0.56 & & 0.52 & -2.16 & 4.96 \\
\hline Energy price inflation, $\mathrm{q} / \mathrm{q}$ & 3,398 & 2.41 & 2.67 & & 11.69 & -46.08 & 43.43 \\
\hline Foreign interest rate, $\%$ & 3,398 & 2.67 & 2.71 & & 3.50 & -5.20 & 22.00 \\
\hline GDP growth, $\mathrm{q} / \mathrm{q}$ & 3,398 & 1.77 & 1.30 & & 2.66 & -14.55 & 32.74 \\
\hline Inflation, $\mathrm{q} / \mathrm{q}$ & 3,398 & 1.21 & 0.84 & & 1.70 & -19.67 & 18.53 \\
\hline Capital outflows/GDP & 3,398 & -2.19 & -2.14 & & 6.48 & -19.94 & 19.91 \\
\hline Exchange rate change, $\mathrm{q} / \mathrm{q}$ & 3,398 & -0.02 & 0.00 & & 3.44 & -19.06 & 9.94 \\
\hline FX accumulation/GDP & 3,398 & 1.67 & 0.75 & & 4.87 & -26.38 & 36.06 \\
\hline Interest rate, $\%$ & 3,398 & 6.76 & 5.54 & & 5.76 & -6.37 & 76.94 \\
\hline Float, open & Obs & Mean & Median & St. & Dev. & Min & Max \\
\hline GDP growth, q/q & 720 & 1.84 & 1.08 & & 3.27 & -5.30 & 25.19 \\
\hline Inflation, q/q & 720 & 0.86 & 0.67 & & 1.02 & -2.31 & 9.79 \\
\hline Capital outflows/GDP & 720 & -1.29 & -0.76 & & 6.08 & -19.79 & 19.69 \\
\hline Exchange rate change, $\mathrm{q} / \mathrm{q}$ & 720 & -0.61 & -0.47 & & 4.86 & -15.44 & 9.86 \\
\hline FX accumulation/GDP & 720 & 1.15 & 0.37 & & 3.91 & -13.77 & 36.06 \\
\hline Interest rate, $\%$ & 720 & 5.11 & 4.51 & & 4.26 & -4.43 & 21.13 \\
\hline Float, closed & Obs & Mean & Median & St. & Dev. & Min & Max \\
\hline GDP growth, q/q & 429 & 1.42 & 1.17 & & 2.09 & -5.57 & 14.87 \\
\hline Inflation, $\mathrm{q} / \mathrm{q}$ & 429 & 1.96 & 1.51 & & 2.69 & -19.67 & 18.53 \\
\hline Capital outflows/GDP & 429 & -3.41 & -3.16 & & 5.23 & -18.87 & 18.45 \\
\hline Exchange rate change, $\mathrm{q} / \mathrm{q}$ & 429 & 0.39 & 0.36 & & 4.94 & -19.06 & 9.91 \\
\hline FX accumulation/GDP & 429 & 1.89 & 1.18 & & 4.48 & -22.04 & 18.73 \\
\hline Interest rate, $\%$ & 429 & 11.43 & 9.13 & & 9.37 & 0.98 & 76.94 \\
\hline Peg, open & Obs & Mean & Median & St. & Dev. & Min & Max \\
\hline GDP growth, q/q & 1,256 & 1.67 & 1.20 & & 2.44 & -10.02 & 22.93 \\
\hline Inflation, q/q & 1,256 & 0.76 & 0.61 & & 0.86 & -3.51 & 7.26 \\
\hline Capital outflows/GDP & 1,256 & -1.48 & -1.79 & & 7.39 & -19.94 & 19.91 \\
\hline Exchange rate change, $\mathrm{q} / \mathrm{q}$ & 1,256 & -0.02 & 0.00 & & 2.17 & -8.87 & 8.43 \\
\hline FX accumulation/GDP & 1,256 & 1.59 & 0.53 & & 5.28 & -23.81 & 32.46 \\
\hline Interest rate, $\%$ & 1,256 & 5.07 & 4.24 & & 3.89 & -6.37 & 24.62 \\
\hline Peg, closed & Obs & Mean & Median & St. & Dev. & Min & $\operatorname{Max}$ \\
\hline GDP growth, q/q & 728 & 2.16 & 1.81 & & 2.50 & -14.55 & 14.77 \\
\hline Inflation, $\mathrm{q} / \mathrm{q}$ & 728 & 1.78 & 1.32 & & 1.95 & -1.84 & 11.68 \\
\hline Capital outflows/GDP & 728 & -3.68 & -3.20 & & 5.54 & -19.33 & 14.72 \\
\hline Exchange rate change, $\mathrm{q} / \mathrm{q}$ & 728 & 0.16 & 0.03 & & 2.04 & -8.11 & 7.98 \\
\hline FX accumulation/GDP & 728 & 2.41 & 1.69 & & 5.32 & -26.38 & 24.83 \\
\hline Interest rate, $\%$ & 728 & 8.68 & 7.50 & & 4.75 & 1.01 & 27.12 \\
\hline
\end{tabular}


Table 3: Variance decomposition, share of the variance of fluctuations in the domestic policy rate that are explained by shocks to each variable.

\begin{tabular}{|c|c|c|c|c|c|c|c|c|c|c|}
\hline \multicolumn{11}{|c|}{ Float, Open } \\
\hline Horizon & $y_{t}^{*}$ & $\pi_{t}^{*}$ & $\pi_{t}^{e n e r}$ & $r_{t}^{*}$ & $y_{t}$ & $\pi_{t}$ & $o_{t}$ & $x r_{t}$ & $f x_{t}$ & $r_{t}$ \\
\hline 4 quarters & 0.39 & 2.82 & 0.20 & 0.21 & 0.03 & 16.72 & 0.18 & 1.94 & 3.42 & 74.09 \\
\hline 8 & 2.42 & 4.69 & 0.67 & 0.45 & 0.09 & 19.85 & 0.55 & 2.51 & 4.16 & 64.61 \\
\hline 12 & 4.75 & 5.34 & 0.94 & 0.67 & 0.17 & 20.27 & 0.73 & 2.61 & 4.33 & 60.18 \\
\hline 16 & 6.69 & 5.67 & 1.09 & 0.87 & 0.22 & 20.19 & 0.82 & 2.62 & 4.36 & 57.48 \\
\hline 20 & 8.16 & 5.87 & 1.18 & 1.04 & 0.24 & 20.01 & 0.86 & 2.60 & 4.35 & 55.68 \\
\hline \multicolumn{11}{|c|}{ Float, Closed } \\
\hline Horizon & $y_{t}^{*}$ & $\pi_{t}^{*}$ & $\pi_{t}^{\text {energy }}$ & $r_{t}^{*}$ & $y_{t}$ & $\pi_{t}$ & $o_{t}$ & $x r_{t}$ & $f x_{t}$ & $r_{t}$ \\
\hline 4 quarters & 0.06 & 1.72 & 0.27 & 0.13 & 0.09 & 1.04 & 0.20 & 1.38 & 5.82 & 89.30 \\
\hline 8 & 0.06 & 2.44 & 0.42 & 0.12 & 0.06 & 0.90 & 0.74 & 1.84 & 8.83 & 84.59 \\
\hline 12 & 0.05 & 2.57 & 0.49 & 0.12 & 0.04 & 0.80 & 1.21 & 1.96 & 10.24 & 82.52 \\
\hline 16 & 0.05 & 2.59 & 0.52 & 0.13 & 0.04 & 0.74 & 1.47 & 2.01 & 10.95 & 81.51 \\
\hline 20 & 0.04 & 2.59 & 0.53 & 0.14 & 0.04 & 0.70 & 1.63 & 2.03 & 11.34 & 80.97 \\
\hline \multicolumn{11}{|c|}{ Peg, Open } \\
\hline Horizon & $y_{t}^{*}$ & $\pi_{t}^{*}$ & $\pi_{t}^{\text {energy }}$ & $r_{t}^{*}$ & $y_{t}$ & $\pi_{t}$ & $o_{t}$ & $x r_{t}$ & $f x_{t}$ & $r_{t}$ \\
\hline 4 quarters & 2.66 & 3.79 & 0.29 & 1.09 & 0.01 & 3.43 & 0.06 & 0.66 & 1.61 & 86.40 \\
\hline 8 & 6.60 & 5.96 & 0.64 & 5.35 & 0.01 & 4.59 & 0.27 & 0.69 & 2.21 & 73.67 \\
\hline 12 & 10.34 & 6.87 & 0.87 & 10.54 & 0.02 & 4.53 & 0.38 & 0.64 & 2.25 & 63.55 \\
\hline 16 & 13.19 & 7.23 & 1.02 & 15.25 & 0.02 & 4.21 & 0.40 & 0.58 & 2.11 & 55.98 \\
\hline 20 & 15.18 & 7.35 & 1.10 & 19.06 & 0.02 & 3.88 & 0.39 & 0.53 & 1.96 & 50.52 \\
\hline \multicolumn{11}{|c|}{ Peg, Closed } \\
\hline Horizon & $y_{t}^{*}$ & $\pi_{t}^{*}$ & $\pi_{t}^{\text {energy }}$ & $r_{t}^{*}$ & $y_{t}$ & $\pi_{t}$ & $o_{t}$ & $x r_{t}$ & $f x_{t}$ & $r_{t}$ \\
\hline 4 quarters & 0.32 & 2.42 & 0.01 & 1.27 & 0.33 & 1.26 & 0.37 & 0.32 & 3.15 & 90.55 \\
\hline 8 & 1.42 & 3.77 & 0.13 & 3.77 & 0.38 & 3.70 & 0.71 & 0.44 & 3.54 & 82.14 \\
\hline 12 & 2.94 & 4.40 & 0.31 & 6.67 & 0.37 & 5.37 & 0.76 & 0.48 & 3.31 & 75.41 \\
\hline 16 & 4.44 & 4.72 & 0.47 & 9.38 & 0.35 & 6.15 & 0.72 & 0.48 & 3.06 & 70.23 \\
\hline 20 & 5.72 & 4.88 & 0.58 & 11.63 & 0.33 & 6.41 & 0.68 & 0.47 & 2.88 & 66.41 \\
\hline
\end{tabular}


Table 4: Modesty statistics for each of the domestic variables in the model at forecast horizon $\mathrm{h}$ for the hypothetical shock to the domestic interest rate.

\begin{tabular}{|c|c|c|c|c|c|c|}
\hline \multicolumn{7}{|c|}{ Float, Open } \\
\hline Horizon & $y_{t}$ & $\pi_{t}$ & $o_{t}$ & $x r_{t}$ & $f x_{t}$ & $r_{t}$ \\
\hline 4 quarters & -0.001 & -0.006 & 0.002 & -0.001 & 0.000 & -0.031 \\
\hline 8 & -0.003 & -0.010 & 0.006 & -0.002 & -0.001 & -0.032 \\
\hline 12 & -0.005 & -0.012 & 0.007 & -0.002 & -0.001 & -0.030 \\
\hline 16 & -0.005 & -0.013 & 0.008 & -0.002 & -0.001 & -0.028 \\
\hline 20 & -0.005 & -0.012 & 0.008 & -0.002 & -0.001 & -0.026 \\
\hline \multicolumn{7}{|c|}{ Float, Closed } \\
\hline Horizon & $y_{t}$ & $\pi_{t}$ & $o_{t}$ & $x r_{t}$ & $f x_{t}$ & $r_{t}$ \\
\hline 4 quarters & 0.001 & 0.004 & -0.001 & 0.001 & 0.000 & 0.016 \\
\hline 8 & 0.001 & 0.004 & -0.001 & 0.001 & 0.000 & 0.010 \\
\hline 12 & 0.001 & 0.004 & -0.001 & 0.000 & 0.000 & 0.008 \\
\hline 16 & 0.001 & 0.003 & 0.000 & 0.000 & 0.000 & 0.007 \\
\hline 20 & 0.001 & 0.003 & 0.000 & 0.000 & 0.000 & 0.007 \\
\hline \multicolumn{7}{|c|}{ Peg, Open } \\
\hline Horizon & $y_{t}$ & $\pi_{t}$ & $o_{t}$ & $x r$ & $f x_{t}$ & $r_{t}$ \\
\hline 4 quarters & -0.002 & -0.003 & 0.001 & 0.000 & 0.001 & -0.084 \\
\hline 8 & -0.008 & -0.013 & 0.009 & -0.001 & 0.005 & -0.127 \\
\hline 12 & -0.012 & -0.020 & 0.016 & -0.001 & 0.007 & -0.134 \\
\hline 16 & -0.013 & -0.023 & 0.020 & -0.001 & 0.008 & -0.128 \\
\hline 20 & -0.014 & -0.023 & 0.021 & -0.001 & 0.008 & -0.117 \\
\hline \multicolumn{7}{|c|}{ Peg, Closed } \\
\hline Horizon & $y_{t}$ & $\pi_{t}$ & $o_{t}$ & $x r_{t}$ & $f x_{t}$ & $r_{t}$ \\
\hline 4 quarters & -0.002 & 0.000 & 0.002 & -0.003 & 0.004 & -0.078 \\
\hline 8 & -0.004 & 0.001 & 0.005 & -0.006 & 0.008 & -0.095 \\
\hline 12 & -0.004 & 0.001 & 0.007 & -0.008 & 0.010 & -0.097 \\
\hline 16 & -0.005 & 0.002 & 0.007 & -0.008 & 0.010 & -0.091 \\
\hline 20 & -0.004 & 0.002 & 0.007 & -0.008 & 0.010 & -0.083 \\
\hline
\end{tabular}


Figure 1: Responses of home variables following a 1 p.p. increase in the foreign policy rate in a country with a floating currency and an open capital account.
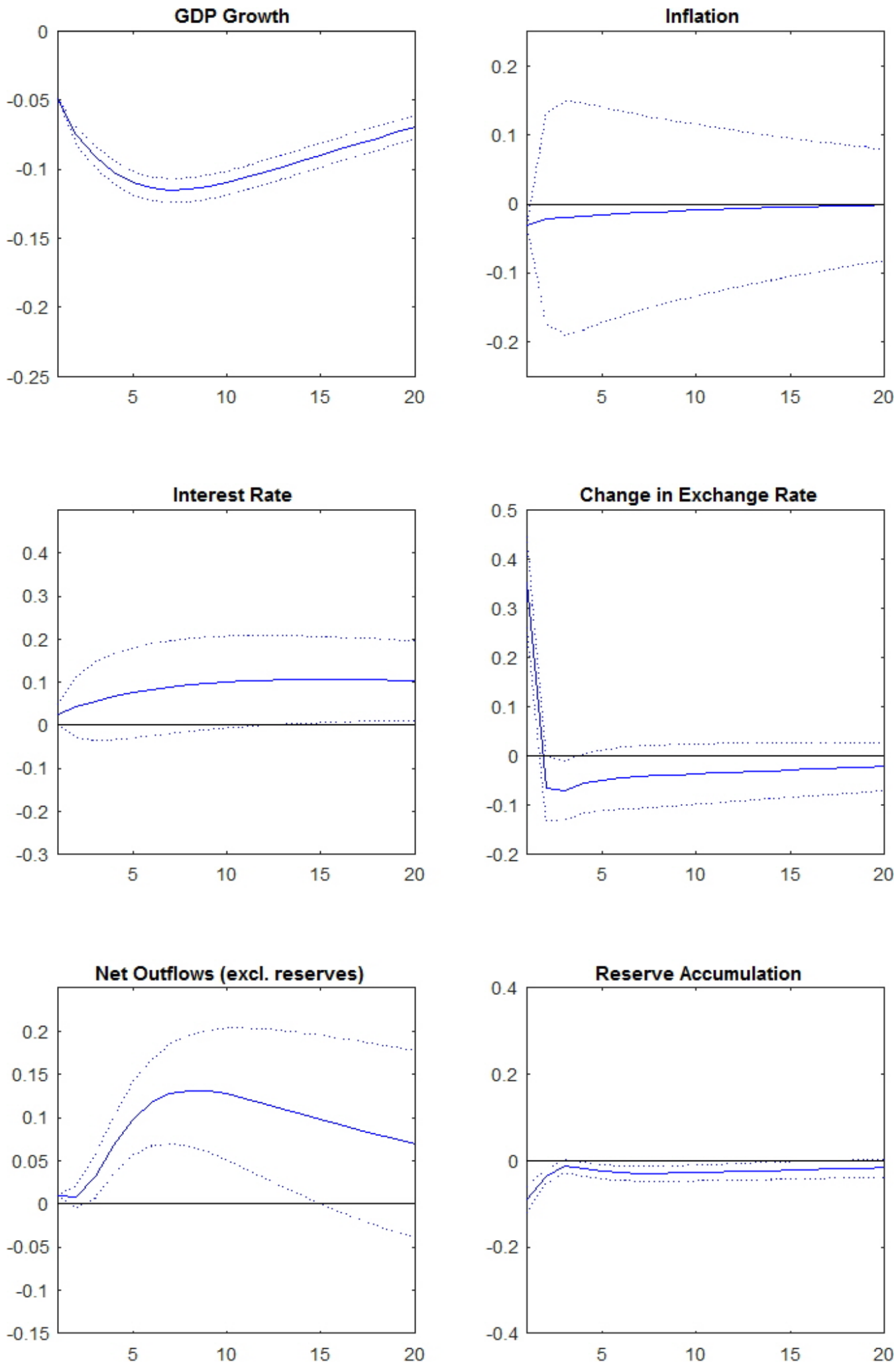

Notes: Red dashed lines are \pm 1 Standard error bands 
Figure 2: Responses of home variables following a 1 p.p. increase in the foreign policy rate in a country with a floating currency and a closed capital account.
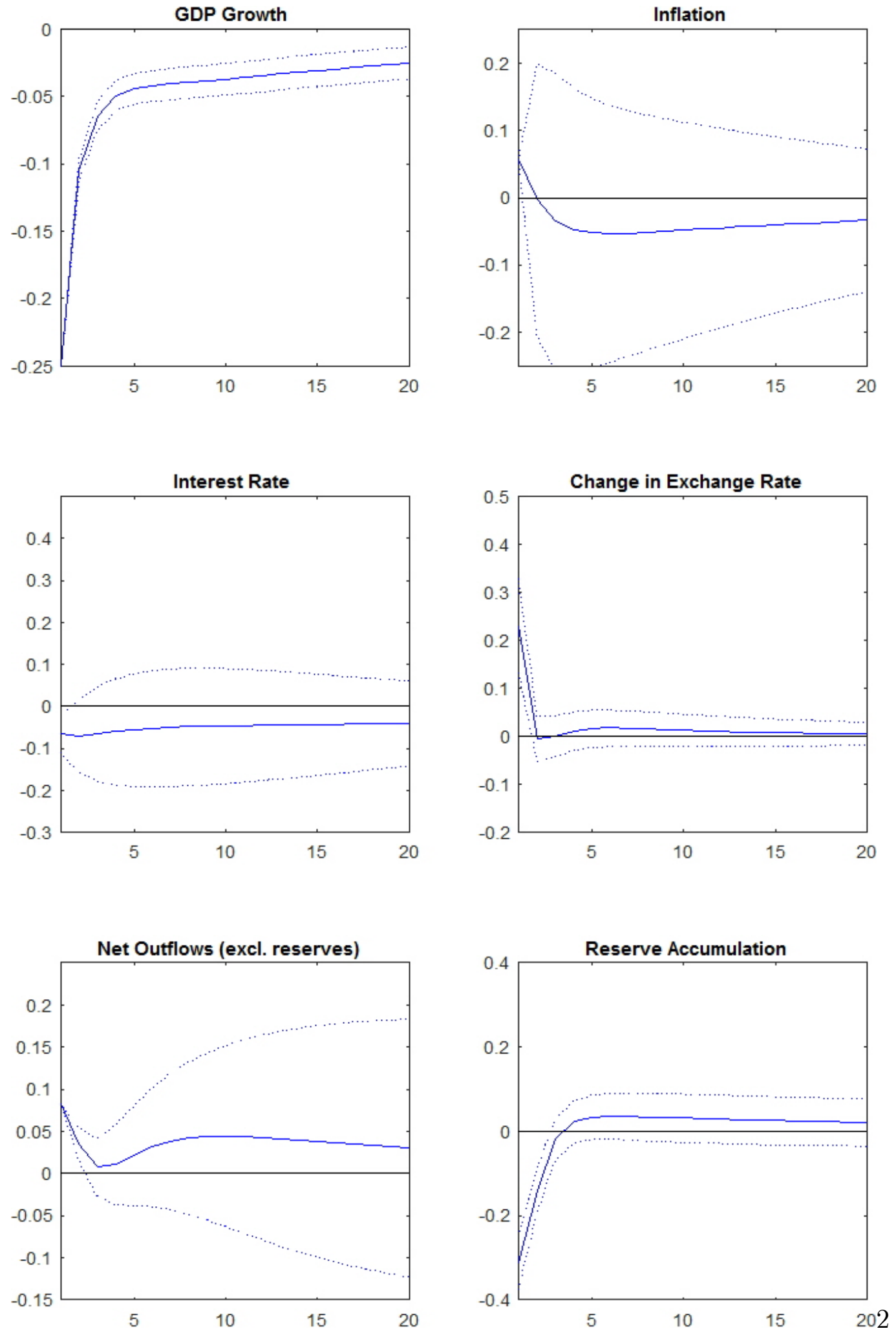

Notes: Red dashed lines are \pm 1 Standard error bands 
Figure 3: Responses of home variables following a 1 p.p. increase in the foreign policy rate in a country with a fixed currency and an open capital account.
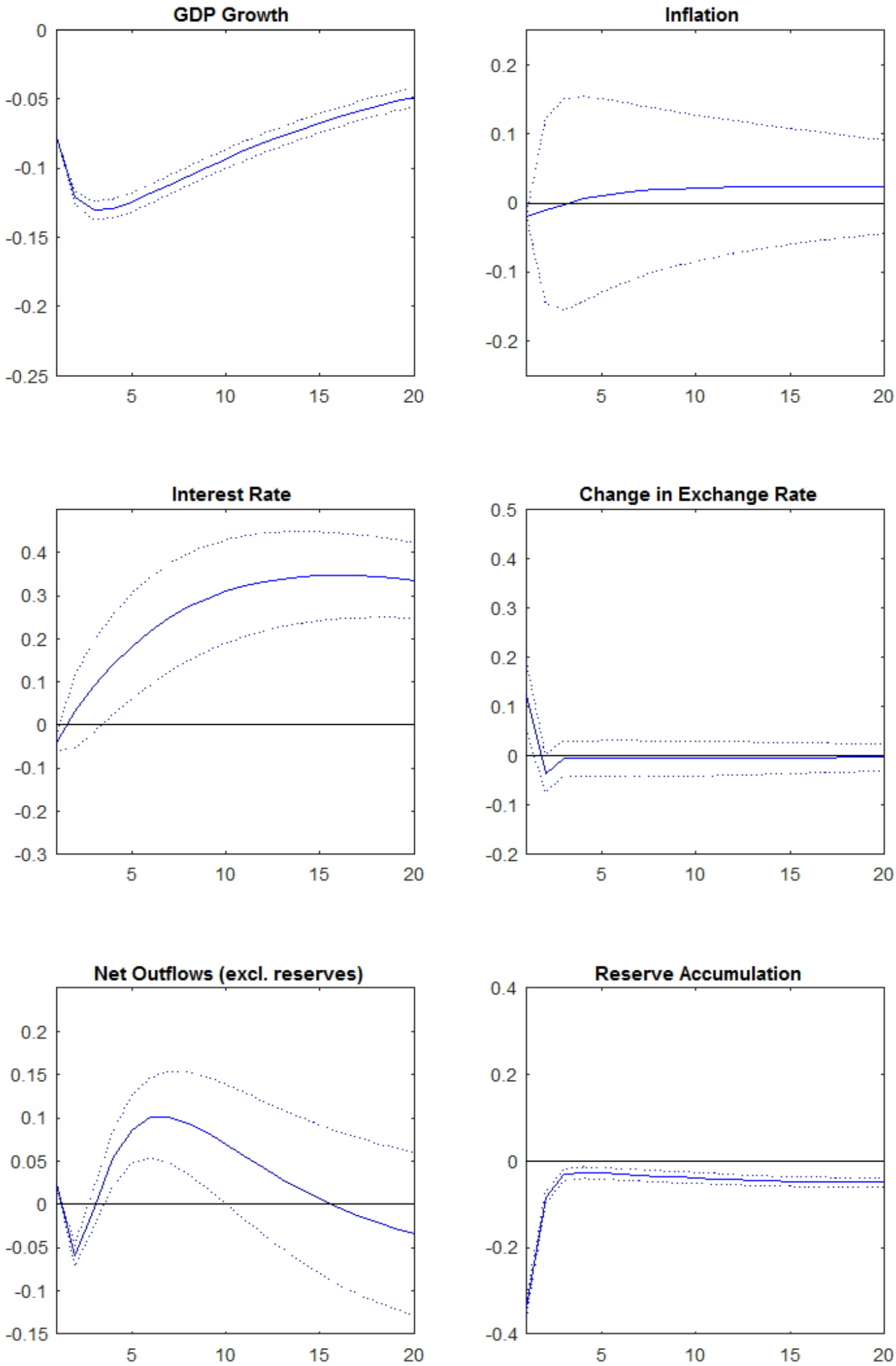

Notes: Red dashed lines are \pm 1 Standard error bands 
Figure 4: Responses of home variables following a 1 p.p. increase in the foreign policy rate in a country with a fixed currency and a closed capital account.
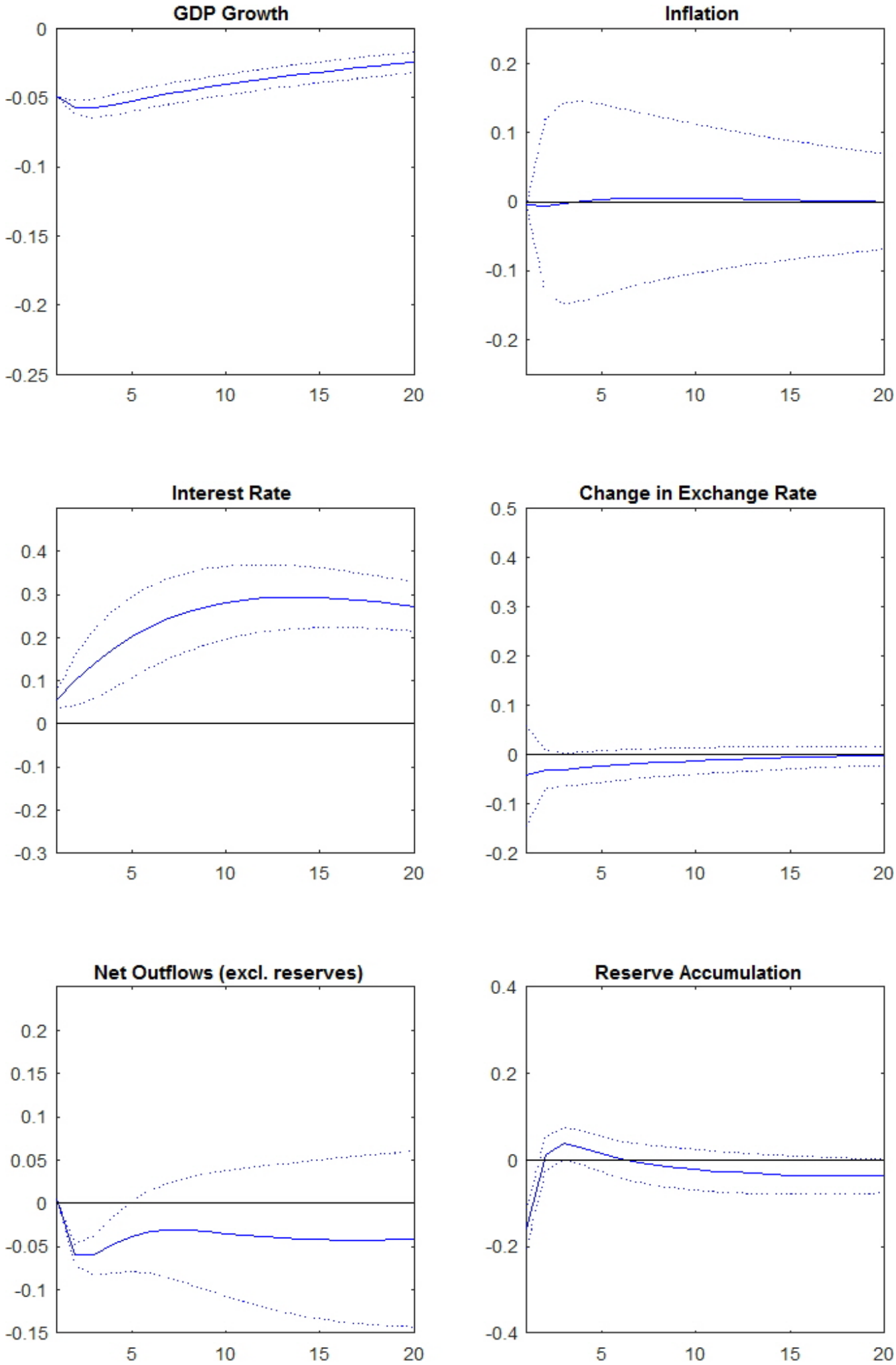

Notes: Red dashed lines are \pm 1 Standard error bands 
Figure 5: Counterfactual shocks to the home policy rate that would be necessary to keep the home policy rate constant following a shock to the foreign policy rate.

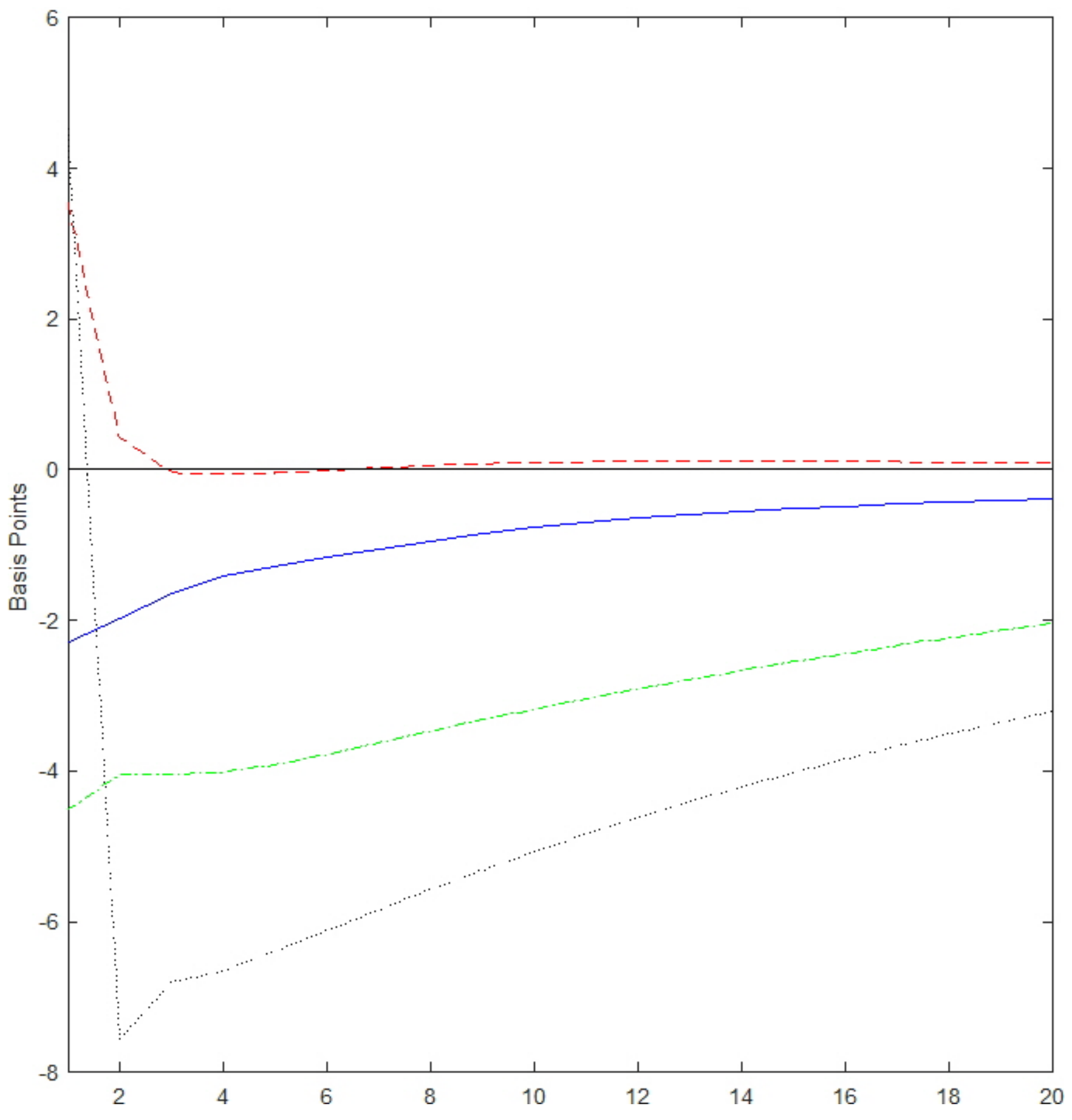

Notes: Blue solid line is the series of counterfactual shocks in the subset of countries with a floating currency and an open capital account, the red dashed line is for the subset with the floating currency and the closed capital account, the black dotted line is for the subset with the fixed currency and the open capital account, the green dash-dot line is for the subset with a fixed currency and a closed capital account. 
Figure 6: Responses of net capital outflows in the actual model and in the counterfactual model where the home policy rate is held constant.
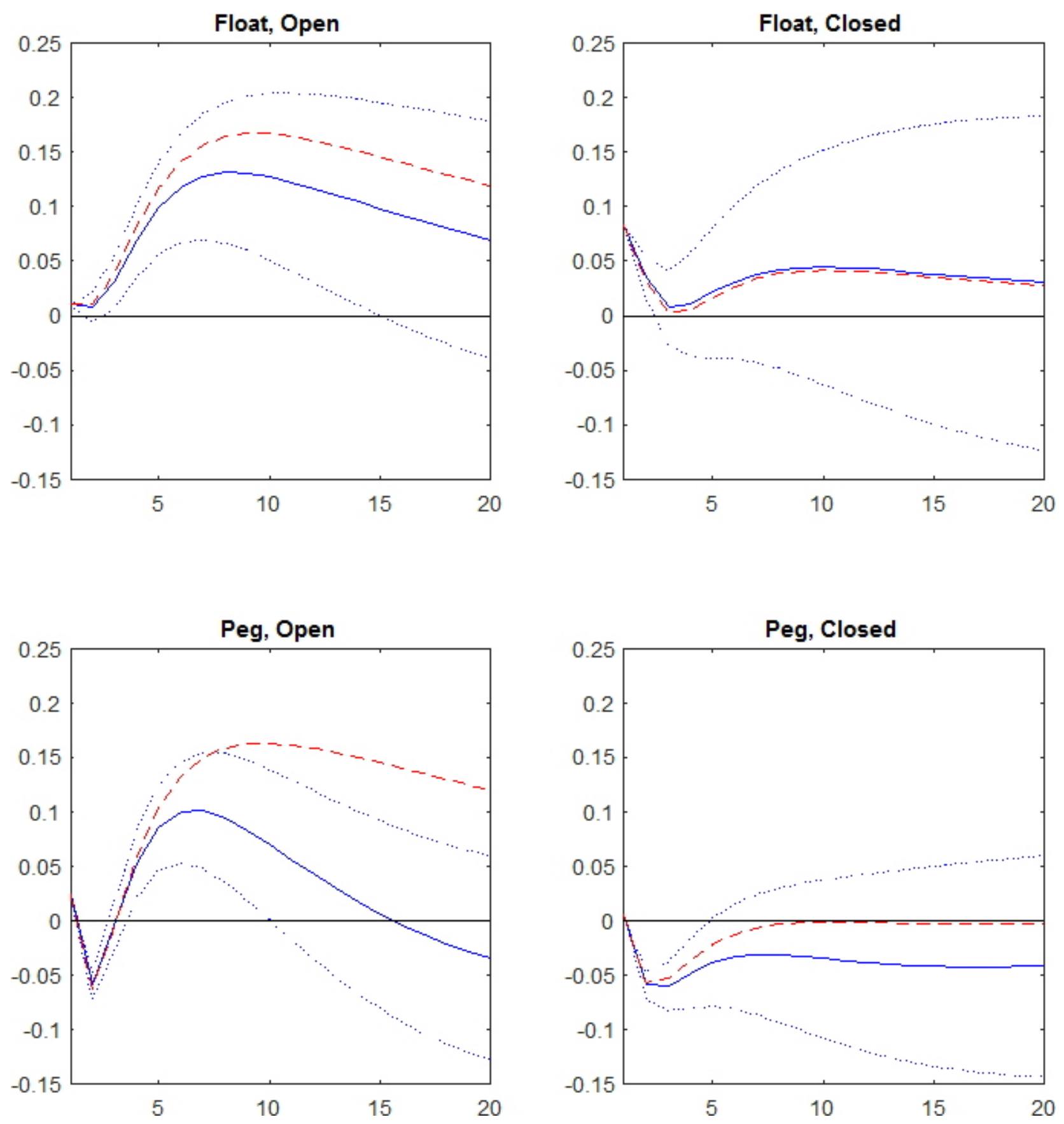

Notes: Blue solid line is the actual response, the red dashed line is the counterfactual response where the home policy rate is held constant. 